\section{Avaliação dos níveis séricos de cortisol e dehidroepiandrosterona em pacientes com malária por Plasmodium falciparum não-complicada}

\begin{abstract}
O objetivo da pesquisa foi avaliar o
\end{abstract} comportamento dos níveis séricos de cortisol e dehidroepiandrosterona (DHEA) em pacientes com malária por Plasmodium falciparum. Como o cortisol apresenta um efeito imunossupressor e o DHEA um efeito imunoestimulador, estudouse a correlação entre os níveis destes esteróides e a condição clínica do paciente de malária. A amostra constou de 24 pacientes com malária por $P$. falciparum não-complicada, sendo 18 do sexo masculino e 6 do sexo feminino, com idade variando de 15 a 47 anos, 12 primoinfectados e 12 multi-infectados, provenientes de área endêmica de malária da Amazônia. Coletaramse amostras diárias de sangue de 20 em 20 minutos no pré-tratamento (D0), 24 horas após o início da medicação (D1) e no $8^{\circ}$ dia de acompanhamento (D7), quando o paciente já se encontrava assintomático. Todos os pacientes apresentavam parasitemia negativa em D7. Dosaram-se: os níveis séricos de cortisol em D0, D1 e D7; DHEA em D0 e D7; os níveis de anticorpos totais IgG anti- $P$. falciparum, anti- $P$. vivax, e anticorpos IgM anti- $P$. falciparum em D0. Comparam-se os níveis séricos de cortisol dos três dias, concluindo-se que os níveis de cortisol eram significativamente mais elevados em DO do que nos outros dias. Foram correlacionados os níveis de cortisol com a parasitemia, obtendo-se como significativas as correlações entre cortisol D0 e parasitemia D1, assim como cortisol D1 com parasitemia D1, levando-se a deduzir que o cortisol pode interferir na resposta inicial à terapêutica de pacientes com malária por $P$. falciparum. O cortisol foi correlacionado com a temperatura, tempo de evolução da doença, níveis de anticorpos lgG anti- $P$. falciparum, não se obtendo resultados estatisticamente significativos, levando a inferir que a temperatura não interfere nos níveis de cortisol e o mesmo não interfere nos níveis de anticorpos, e não apresenta variações

\section{Evaluation of both cortisol and dehidroepiandrosterone levels in patients with non- complicated malaria due to Plasmodium falciparum}

The main purpuse of our study was to determine the levels of both cortisol and dehydroepiandrosterone (DHEA) in serum samples from patients suffering from Plamodium falciparum malaria. Since cortisol is potentially immunosupressive, and, conversely, DHEA is inherently immunopotentially, we sought to assess the possible association between serum levels of these steroids and patient's clinical conditions. We enrolled to participate in this study 24 patients aged 12 to 47 years, of whom 18 were male and 6 female, suffering from uncomplicated $P$. falciparum malaria. All patients lived in areas of the Amazon were malaria is endemic. Half of them were found to be primoinfected, whereas the others were being reinfected by $P$. falciparum when recruited for this investigation. Blood samples were obtained from each patients as follows: at 20-minutes intervals during the pre-treatment phase (i. e. on day 0, D0), 24 hours after starting drug therapy (D1) and at the 8th day of follow-up (D7), when patients were asymptomatic. All patients at D7 presented with negative parasitemia. Serum levels of cortisol and DHEA were measured on D0, D1 and D7 and D0 and D7, respectively. In addition, the determination of $\lg \mathrm{G}$ antibodies to both $P$. falciparum and $P$. vivax was performed only on D0. Our results indicated that levels of cortisol in serum samples collected on D0 were significantly higher than those of D1 and D7. High levels of cortisol on D0/D1 and significant parasitemia on D1 led us to postulated that this corticosteroid may interfere with the initial response of $P$. falciparum-infected patients to treatment. The cortisol levels did not correlate with the intensity of fever, duration of illness and the levels of IgG antibories to P. falciparum. These findings suggest that temperature does not interfere with the cortisol levels, and these, on the other land, do not significantly ralate to either antibody response or the duration of

Recebido para publicação em 12/12/97. 
importantes com o tempo de evolução da doença. Os níveis de DHEA em D0, foram significativamente mais elevados do que em D7, apesar dos pacientes estarem sintomáticos há mais de um dia, já que um estímulo mantido do eixo hipotálamo-hipófise-adrenal (HPA) leva a uma diminuição deste esteróide. O DHEA foi correlacionado com a parasitemia, obtendo-se um resultado significativo na correlação DHEA D0 com parasitemia D1. A correlação entre cortisol e DHEA em D0 não foi significativa $(p=$ 0,057 ), porém este resultado leva a crer que o DHEA acompanha o aumento dos níveis de cortisol. Obteve-se uma correlação negativa entre DHEA e tempo de evolução de doença, apesar destes níveis estarem aumentados no prétratamento. Calculou-se a correlação parcial entre cortisol, DHEA e temperatura, concluindo-se que a temperatura interfere positivamente na correlação cortisol e DHEA. Uma vez que a febre reflete o momento em que ocorre a lise das hemácias secundária a esquizogonia, provavelmente esta lise com conseqüente liberação de citocinas serve como um fator agudizador da estimulação do eixo HPA, sugerindo que a liberação dos dois hormônios apresenta mecanismo comum. A correlação entre DHEA e anticorpos não foi significativa, portanto o DHEA não deve interferir na produção de anticorpos de pacientes com malária por P. falciparum. illness. The DHEA levels were found to be significantly more elevated on D0 than on D7, even though patients were already symptomatic for more than one day when first serum samples was taken. The progressive decrease in the DHEA levels is therefore likely to be mediated by a continuous stimulus from the hypothalamicpituitary-adrenal (HPA) axis. Similarly to cortisol, the DHEA levels on D0 correlated significantly with D1 parasitemia. Thus, it is suggested that in cortisol levels paralels that for DHEA. Of interest, the DHEA serum levels seem to inversely correlate with the duration of illness, in spite of high levels of this steroid detected at the pretreatment phase. A not significant correlation has been noted if cortisol and DHEA serum levels are compared with temperature. This clinical parameter, however, was found to directly interfere with the correlation that exist between both cortisol and DHEA levels. It is known that fever reflects the occasion when erythrocytes disrupt from the schizogony, with release of cytokines, which act as an acute stimulating factor for the HPA axis. It would therefore be proposed that liberation of both hormones has a commom mechanism. The lack of significant interrelationships between DHEA levels and IgG antibodies indicates that this hormone does not seem to interfere with the production of antibodies by $P$. falciparum infected patients.

Rosana Maria Feio Libonati

Tese apresentada ao Núcleo de Medicina Tropical da Universidade Federal do Pará para obtenção do Título de Mestre.

Belém, PA, Brasil, 1997 